\title{
CONTRACT AS ASSUMPTION AND CONSIDERATION THEORY: A REASSESSMENT OF WILLIAMS $V$ ROFFEY BROS
}

\author{
Francis Dawson*
}

This article considers various aspects of the doctrine of consideration in the light of Professor Coote's recent book "Contract as Assumption". Whilst a voluntary assumption of a legal duty is the essence of a contractual obligation, not every promise given in exchange for another promise with the intention to create legal obligations becomes enforceable in contract. Thus there is no contract where A promises to give property to $B$ and B promises to accept it. The Law discriminates between promises given for value and promises which are illusory or gratuitous. It does so by examining the content of the counter-promise (in the above example B's promise to accept) and requires that the performance of the obligation to be undertaken in the reciprocal promise confers a benefit on the promisor (in the example above A) or constitutes a detriment to the counter-party. It follows that whether a purported assumption of liability contained in a promise is enforceable is answered in our law by asking whether the promise is supported by consideration - for example whether what the counter-party has agreed to do is for the benefit of the promisor or to the detriment of the counter-party. It is also suggested that the concept of a practical benefit where an existing legal duty is sought to be modified has respectable historical antecedents which tend to support the reasoning in the controversial decision in Williams v Roffey Bros. Finally, Equity's traditional reluctance to enforce a covenant made under seal which is not exchanged for value is re-examined, and the significance of recent statutory reforms adverted to.

* Solicitor, Auckland. 


\section{INTRODUCTION}

In 2010 Hart published an anthology of the major publications of Professor Coote in a work entitled Contract as Assumption. ${ }^{1}$ The theme that runs through the collection is that a contractual promise creates a binding obligation not because it is imposed extra upon the coincidence of offer acceptance and consideration but because a contracting party using the means provided by the law has assumed the liability.

Coote argues that acceptance of this approach enables one to view the obligation created by deed as a genuine contract. ${ }^{2}$ The theory also provides clear answers to the existing legal duty cases: there can be no consideration and no contract where the promise made is to perform an existing contractual duty to the same promisee, for such a promise is a tautology and no new obligation can be assumed. ${ }^{3}$ But the objection disappears, so it is argued, in the case of a promise to perform a duty owed to a third person.

For that reason it is argued that the important English Court of Appeal decision in Williams $v$ Roffey Bros \& Nicholls (Contractors) Ltd 4 is wrongly decided. In that case, consideration was found to be present in the practical benefit received by the promisor even though the promise was to perform an existing contractual duty. The promise of the performance of an obligation that is already owed to the promisor cannot constitute consideration as it provides nothing that is not already the promisor's right. ${ }^{5}$

The decision in Williams $v$ Roffey Bros is certainly controversial ${ }^{6}$ but its reasoning has been followed twice in the New Zealand Court of Appeal $^{7}$ and the idea that a practical benefit to be received by the promisor constitutes good consideration was central to both decisions.

1 Brian Coote Contract as Assumption: Essays on a Theme (Hart Publishing, Oxford, 2010). The book contains essays on a number of other topics (including privity, exception clauses, the scope of negligence liability and damages) where the relevance of the theme is explored.

2 Ibid, at 43.

3 Ibid, at 45.

4 Williams v Roffey Bros \& Nicholls (Contractors) Ltd [1991] QB 1 (CA).

5 Coote, above n 1 , at 58-59.

6 It was not followed by the English Court of Appeal in Re Selectmove Ltd [1995] 1 WLR 474 (CA), a decision involving a promise by a creditor to take part of his debt in instalments in settlement of the full debt. In that case Peter Gibson LJ observed at 481:

When a creditor and a debtor who are at arm's length reach agreement on the payment of the debt by instalments to accommodate the debtor, the creditor will no doubt always see a practical benefit to himself in so doing. In the absence of authority there would be much to be said for the enforcement of such a contract. But, that was a matter expressly considered in Foakes v Beer, yet held not to constitute good consideration in Law. 
Coote's idea that it is assumption of responsibility which underlies all contractual liability appears to the writer to express a fundamental truth about obligation in contract. After all, a very strong High Court of Australia once said: "It is of the essence of contract, regarded as a class of obligations, that there is a voluntary assumption of a legally enforceable duty." 8

Nevertheless, Williams v Roffey Bros when examined in the light of Contract as Assumption, causes one to reflect on a number of questions relating to consideration theory. Does the formal contract require consideration? Why are mutual promises consideration for each other? Where does practical benefit to the promisor fit in to a theory based on assumption of responsibility? Is practical benefit consistent with the ideas underlying Foakes v Beer and similar cases which hold that it is an illusory promise to promise to perform what you are already legally obliged to perform?

Part I of this essay will consider the formal contract, and will enquire into the supposed rule that specific performance will not be decreed of a formal contract in the absence of consideration being supplied to the promisor by the promisee. Clearly if equity withholds its principal remedy unless consideration is supplied by the promisee, the idea that an assumption of a legally enforceable duty underlies liability in a formal contract must be very substantially qualified. ${ }^{9}$ It will be argued that there is no basis in principle for a blanket denial of equity's intervention to grant specific performance of formal contracts because of the absence of consideration.

In Part II it will be demonstrated that Professor Coote's insight accords with the reasons which the courts originally gave in actions on the case for enforcing promises. In these early cases the courts held that the relevant consideration was the mutual promises given in exchange for each other. Here it will be argued that a promise is not enforceable simply because it is exchanged for another promise and the promisor intends to assume legal responsibility. It is not every promise given in exchange for another promise that is enforceable and it is not everything which the parties agree upon as the requested exchange which the law will treat as sufficient consideration. It will be shown that the content of the promise is examined and that the concepts of benefit to the promisor and detriment to the promisee are central to determining whether a promise is enforceable, and are the law's method of screening gifts and illusory promises from promises in which something of

7 Attorney-General for England and Wales v R [2002] 2 NZLR 91 (CA) at 109; Antons Trawling Co Ltd v Smith [2003] 2 NZLR 23 (CA) at 45. And see Musumeci v Winadell Pty Ltd (1994) 34 NSWLR 723 (SC) where in order to ensure a tenant remained in occupation a landlord agreed with the tenant to reduce the rent by a third (held by Santow J binding).

8 Australian Woollen Mills Pty Ltd v Commonwealth (1954) 92 CLR 424 at 457 per Dixon CJ, Williams, Webb, Fullagar and Kitto JJ.

9 See Pollock Principles of Contract (13th ed, Stevens, London, 1950) at 157-158: "The rule that a Court of equity will not grant specific performance of a gratuitous agreement is so well settled ... that it is needless to cite further authorities for it: and it is not to be overlooked that whereas the other rules that limit the application of this peculiar remedy are of a more or less discretionary kind ... this is an unqualified substantive rule." 
value is to be exchanged. In other words, although one may agree that it is the reciprocal exchange of enforeceable promises which is the consideration, it is still necessary to test whether the promise given to the counterparty (or the counter promise acquired in exchange) gives rise to an enforceable obligation. This requires an assessment of the content of the promise and whether, if that promise were to be performed, that promise would confer a benefit on the counterparty or occasion a detriment to the person making the promise.

Against this background it will be suggested in Part III that the reasoning in Williams $v$ Roffey Bros is similar to that found in a number of early cases on consideration. It will be seen that these cases distinguish between an act which was a detriment to the promisee and an act which conferred a benefit to the promisor. It was a sufficient consideration if either of the two limbs were met and from the earliest times an act which might not constitute a detriment to the promisee (because the promisee was already under an existing duty to perform that act) might nevertheless be held to be sufficient to support a promise if it conferred a benefit on the promisor and moved from the promisee. Accordingly, it will be suggested that the promise to perform an existing contractual duty by the promisee may in certain circumstances not be an illusory promise, but may confer a benefit on the promisor and if it does it will then fall within the established boundaries of consideration. For that reason it will be suggested that the reasoning in Williams $v$ Roffey Bros may be supported.

\section{A Part I}

The idea that a promisor himself assumes liability in contract by using the means provided by law is well illustrated in the creation of the formal contract. Historically, English law recognised that a promise made in writing under seal and delivered to the promisee was binding on the promisor as from the moment of delivery. ${ }^{10}$

The formalities to the creation of an obligation are now to be found in s 9 of the Property Law Act 2007. Today signing and attestation are the material parts of the execution of a deed, ${ }^{11}$ and it is clear that until delivery the deed is ineffectual, and that it is only on delivery that the deed becomes binding. ${ }^{12}$

10 Goddard v Denton (1584) 2 Co Rep 4b at 5a, 76 ER 396 (CP) at 398 and 400: "... there are but three things of the essence and substance of a deed, that is to say, writing in paper or parchment, sealing and delivery ... And when a deed is delivered it takes effect by delivery and not from the day of the date."

11 Property Law Act 2007, s 9(2).

12 Property Law Act 2007, s 9(1)(c) and s 9(9). It may be, however, that the old common law ideas on what constitutes a delivery will continue to govern, and that delivery will be interpreted as meaning any act done evincing an intention to be presently bound. In Xenos $v$ Wickham (1867) LR 2 HL 296 (HL) Lord Blackburn suggested that anything which clearly manifests the intention of the obligor that the formal contract shall become presently binding will be sufficient (at 312 ): 
The significant point for present purposes is that the covenantor assumes a binding obligation by executing the deed and by complying with the formalities set out in the Property law Act 2007. If the formalities are observed there will be a binding contractual obligation. There is no need for the covenantee to show that he or she provided consideration for the promise. The law assists a volunteer, and a volunteer is entitled to claim damages for breach of covenant, either as a party to the deed or as a designated beneficiary of the covenant in the deed. ${ }^{13}$

Cannon $v$ Hartley ${ }^{14}$ is a good illustration of the central idea. Mr and Mrs Hartley entered into a formal contract governing their separation, and made mutual promises to each other. Mr Hartley then made separate promises to his daughter, including a promise that if he should become entitled to any money exceeding $£ 1,000$ he would settle one half of that money on trust for himself for life, then for his wife for life and subject thereto in trust for his daughter absolutely. The daughter (Mrs Cannon) was a party to the deed. It was common ground that the daughter was a volunteer and had not provided any consideration. Mr Hartley became entitled to property on the death of his father. His wife having died in the meantime, he failed to comply with his obligation to settle the property on trust for his daughter. His daughter brought an action on the contract as a party to the deed, and as a promisee.

She was met with a full-scale attack on the extent of a promisor's liability to a promisee who had not provided consideration under a formal contract. It was argued that since a court of equity would not assist a volunteer and would not permit a covenantee under a formal contract to claim specific performance, a court of law should, after the Judicature Acts, follow the equitable rule and refuse to award damages to a volunteer even though the promise was made under seal. Re Pryce ${ }^{15}$ in which Eve J had said the following was relied upon: ${ }^{16}$

... volunteers have no right whatever to obtain specific performance of a mere covenant which has remained as a covenant and has never been performed. ... Nor could damages be awarded either in this court, or, I apprehend, at law, where, since the Judicature Act, the same defences would be available to the defendant as would be raised in an action brought in this Court for specific performance.

The mere affixing the seal does not render it a deed: but as soon as there are acts or words sufficient to show that it is intended by the party to be executed as his deed, presently binding on him, it is sufficient. The most apt and expressive mode of indicating such an intention is to hand it over, saying: "I deliver this as my deed": but any other words or acts that sufficiently show that it was intended to be finally executed will do as well.

13 Contracts (Privity) Act 1982; and see RJ Bullen "The Rights of Strangers to Contracts under Seal" (1977) 6 Adel L Rev 118

14 Cannon v Hartley [1949] Ch 213 (Ch).

15 Re Pryce [1917] 1 Ch 234 (Ch).

16 Ibid, at 241. 
Romer J's judgment begins with an acceptance of the equitable rule that specific performance will not be granted to a person who has not provided consideration. ${ }^{17}$ But after an examination of the cases relied upon by counsel, especially Re Pryce ${ }^{18}$ and its sister case Re Kay, ${ }^{19}$ the Court found that in none of the cases relied upon had the plaintiff in equity been a party to the deed and a covenantee. It was therefore held that the cases were distinguishable and that the plaintiff was entitled to damages.

The judgment can be criticised for failing to address either of the questions which were fairly before the Court. These were, first, was it actually the case that equity would refuse to grant specific performance to the plaintiff Mrs Cannon, a party to the deed, because she had not provided consideration? And, secondly, if that were the equitable principle, why did it not prevail after the Judicature Act? Why would the Court withhold the equitable remedy of specific performance but grant damages?

The answer to the first question was assumed without discussion, and the second not addressed at all. But it was held unequivocally that Mrs Cannon was entitled to claim damages because $\mathrm{Mr}$ Hartley had so covenanted in a deed. He had undertaken a liability to Mrs Cannon in the form required by law, and was therefore liable. So the curious result is reached that the Court will award damages for breach of a promise under seal but will not award specific performance in respect of a breach of the same promise.

For present purposes, the interest in the judgment rests with the Judge's assumption that specific performance was unavailable to the plaintiff as she had not provided consideration. If that proposition were true it would mean that the essential ingredients for a court of equity's recognition of a promise under seal would be an undertaking to perform in the deed coupled with the provision of consideration to the promisor.

The proposition that equity will not assist a volunteer is supported by all the leading texts. Typical of the statements of law are those to be found in Halsbury ${ }^{20}$ and in Fry: ${ }^{21}$

17 Cannon v Hartley, above n 14, at 217: "It is, of course, well established that in such a case as this a volunteer cannot ask a court of equity to exercise relief of a nature which is peculiar to the jurisdiction of equity...".

18 Re Pryce, above n 15.

19 Re Kay [1939] Ch 329 (Ch), where Simonds J had followed Re Pryce.

20 Halsbury's Laws of England (4th ed, 1983) vol 44 Specific Performance at [405].

21 Edward Fry A Treatise on the Specific Performance of Contracts (6th ed, Sweet \& Maxwell, London, 1985) at 53. And see Joseph Chitty Chitty on Contracts (30th Ed, Sweet \& Maxwell, London, 2008) at [1-108], [3-21], [27-34] to the same effect. 
The Court does not enforce specific performance of contracts which are voluntary whether under seal or not and a party claiming specific performance must show consideration.

The Court will never lend its assistance to enforce the specific execution of contracts which are

voluntary, ... even though they may have the legal consideration of a seal.

The decision usually cited in support is Lord Cottenham's judgment in Jefferys $v$ Jefferys. $^{22}$ In that case a father had covenanted to surrender certain copyholds to trustees to hold on trust for the benefit of his daughters. Lord Cottenham held that a court would not enforce a voluntary contract and said that the principle of the court to withhold its assistance applies equally whether he seeks to have the benefit of a contract, a covenant or a settlement.

It has been suggested by a learned author that the fundamental principle that underlies this restriction is that equity has not regarded the mere giving of a promise under seal as itself creating a situation where it would be equitable that the promise should be performed. It is said that it is the provision of something of value that renders a failure to perform so inequitable that enforcement may be obtained in specie. ${ }^{23}$

This explanation needs further elaboration. It is a first principle of the law of property that a person has it in his power to make a gift of any part of his property. In order that the gift be effective the law requires that the donor must have done everything which according to the nature of the property comprised in the gift is necessary to effect a transfer of title. The law allows a donor to recant at any time prior to the gift becoming effective, and in the absence of special circumstances it is not considered inequitable that there be a change of mind. In the leading cases on the refusal to grant specific performance to volunteers, it will be found that the dispute relates to an incomplete transfer of property, and either the donor has changed his mind or the necessary formalities for a transfer of title have not been complied with. In these cases equity takes the position that if the substance of the promise made under seal is a gift, it will not compel the donor to complete and perfect the gift. The refusal to grant specific performance of the contract under seal thus occurs in support of one of the principles of the law of property. For gifts to be effective in law, the donor must have done everything which was necessary to effect a transfer of title.

One of the leading cases on uncompleted gifts and on equity not assisting a volunteer is Milroy $v$ Lord. In that case Medley executed a deed seeking to transfer certain bank shares to a trustee. So far as material the deed provided: ${ }^{24}$

22 Jefferys $v$ Jefferys (1841) 1 Cr \& Ph 136, 41 ER 443 (Ch).

23 ICF Spry The principles of equitable remedies: injunctions, specific performance and equitable damages (4th ed, Law Book Co, Sydney, 1990) at 56.

24 Milroy v Lord (1862) 4 De G F \& J 264, 45 ER 1185 (QB) at 1186. 
I, Thomas Medley... in consideration of one dollar to me in hand paid, have conveyed, transferred, set over and delivered, and by these presents do convey, transfer, set over and deliver unto Samuel Lord ... fifty shares of the capital stock of the Bank of Louisiana now standing in my name in the books of the said bank, together with the certificate or script thereof numbered $3457 \ldots$ to have and to hold to the said Samuel Lord ... upon the trusts and conditions following, to wit, in trust to collect and receive the dividends and profits of the said stock, and apply them to the use and benefit of the said Eleanor Rainey Dudgeon ... And I the said Samuel Lord do consent and agree to accept this transfer, and I hereby covenant and agree to and with the said Thomas Medley and the said Eleanor Rainey Dudgeon severally and respectively ... that I will observe, perform, fulfil and keep the trusts and conditions hereinbefore declared.

As is well known by all students of the law of trusts the relevant transfer of shares needed to be recorded in the bank's register of shareholders, and no transfer of the bank shares was made into the name of Lord. So when Mr Medley died, the trust had not been constituted. Mr Medley's personal representative resisted the transfer of the shares and argued that there was nothing but an uncompleted gift which since it was voluntary the Court would not complete. But of course there was a formal contract pursuant to which Mr Medley had obliged himself to transfer the shares to Lord, and Lord had also covenanted with Medley and Ms Eleanor Dudgeon that he would perform the conditions. Could not Ms Eleanor claim specific performance against Lord and Medley's representative that Medley perform the promise as covenanted and transfer the shares to Lord? The answer that the Court gave is that specific performance is not available because the instrument was not founded on a valuable consideration. It was merely gratuitous and voluntary: "nor do I think that, voluntary as the instrument was, it contained a contract specifically enforceable against $\mathrm{Mr}$ Medley."25

The premise of this reasoning is that the formal contract does not give rise to a binding obligation in equity's eyes. It is unworthy of equity's intervention because a valuable consideration has not been provided to the promisor. Since no consideration has been provided, it sounds not in obligation but in the territory of revocable promises, for example gifts. The reasoning of that excellent equity Judge, Knight Bruce LJ, in one of the leading cases on volunteers is instructive on equity's whole attitude to the formal contract: ${ }^{26}$

The present case has raised ... a question ... whether an act or intended act of bounty - whether a gift or a promised or intended gift, was in truth a perfect act, a completed gift, resting neither in promise merely, nor merely in unfulfilled intention; or was incomplete, was imperfect, and rested merely in promise or unfulfilled intention.

25 Ibid, at 273 per Knight Bruce LJ.

26 Kekewich v Manning (1851) 1 De G M \& G 176 at 188, 42 ER 519 (Ch) at 524. 
... this question ... is very material. For as, upon one hand, it is, on legal and equitable principles, ... clear that a person, sui juris, acting freely, fairly and with sufficient knowledge, ought to have and has it in his power to make, in a binding and effectual manner, a voluntary gift of any part of his property ... so, on the other, it is as clear ... that a gratuitously expressed intention, a promise merely voluntary, or, to use a familiar phrase, nudum pactum, does not (the matter resting there) bind legally or equitably. I have been speaking of transactions without any sealed writing. But though it is true that in cases where such an intention, such a promise, is expressed in a deed, it may bind generally at law as a covenant by reason of the light in which the particular kind of instrument called a deed is regarded at law, yet in equity, where at least the covenantor is living, or where specific performance of such a covenant is sought, it stands scarcely, or not at all, on a better footing than if it were contained in an instrument unsealed.

In other words equity treats a promise made without consideration to transfer property under seal as a nudum pactum and as revocable. It ignores the covenantor's express undertaking and characterises it as a non-binding imperfect gift capable of revocation and not as a formally binding obligation. ${ }^{27}$ In the writer's view, looked at from the perspective of the law of contract, this is completely untenable for it entirely ignores that the purpose of entering into a deed is to create an obligation which has legal effect and is binding - the very antithesis to a revocable and non-binding nudum pactum promise.

It is clear that this strange outcome has not always been equity's practice. In Beard $v$ Nutthall ${ }^{28}$ Trevor MR had said "... for an agreement though voluntary under hand and seal ought to be decreed by this court". In Edwards v Countess of Warwick, ${ }^{29}$ Lord Macclesfield said that "... I take it to be clear that if I voluntarily, and without any consideration, covenant to lay out money in a purchase of land to be settled on me and my heirs, this Court will compel the execution of such contract, though merely voluntary". In Wycherley $v$ Wycherley, ${ }^{30}$ Lord Henley expressly excepted from the operation of the general rule that courts will not compel the performance of voluntary agreements the specific performance of formal contracts: "I do not mean cases of specialties where the deed itself is evidence of a consideration." In Pulvertoft v Pulvertoft ${ }^{31}$ Lord Eldon had said that it is clear that a voluntary settlement is good as between the parties.

27 Antrobus v Smith (1805) 12 Ves Jun 39, 33 ER 16 (Ch) (not an obligation under seal but illustrative of the general principle); Dillon v Coppin (1839) 4 My \& Cr 647, 41 ER 249 (Ch); Jefferys v Jefferys, above n 22; Ward v Audland (1845) 8 Beav 201, 50 ER 79 (Ch); Kekewich $v$ Manning, above n 26, at 188 per Knight Bruce LJ; Milroy $v$ Lord, above $\mathrm{n} 24$. There are many more cases: see the note to Ward $v$ Audland, at 213.

28 Beard v Nutthall (1686) 1 Vern 427 at 428, 23 ER $564(\mathrm{Ch})$ at 564.

29 Edwards v Countess Dowager of Warwick (1723) 2 P Wms 171 at 176, 24 ER 687 (Ch) at 688.

30 Wycherley $v$ Wycherley (1763) 2 Eden 175 at 177-178, 28 ER $864(\mathrm{Ch})$ at 865.

31 Pulvertoft v Pulvertoft (1811) 18 Ves Jun 84 at 90, 34 ER 249 (Ch) at 252. 
It is also clear that there are exceptions to the generally received view that equity will not assist a volunteer, as may be illustrated by the decision in Mountford $v$ Scott. ${ }^{32}$ There, the plaintiff had obtained an option over a property in London and had paid $£ 1$ for the option. The option allowed the plaintiff to acquire the property at an agreed price at any time during a window of six months. Shortly after the option was granted the defendant resiled from the agreement and said he was no longer prepared to sell. After the purported withdrawal of his offer, the plaintiff accepted the offer contained in the option ${ }^{33}$ and sought specific performance of the resultant contract of sale constituted by the option agreement and the exercise of the option.

It was argued for the defendant that since the court would not grant specific performance if the option had been granted under seal, the court ought not to do so where the consideration was merely nominal. ${ }^{34}$

The Court of Appeal affirmed ${ }^{35}$ the judgment of Brightman $\mathrm{J}$ who held that the option should be specifically enforced, and the resultant contract enforced. Brightman J reasoned that the grant of the option created an equitable interest in the land as from the moment it was created and then said: ${ }^{36}$

It is not the function of equity to protect only those equitable interests which have been created for valuable consideration. If it were not open to the holder of an option gratuitously created to obtain an order for specific performance, it would seem impossible to assert that an option creates, as it does, an equitable interest in the land.

Professor Sharpe is surely correct to have observed that if the courts are prepared to grant specific performance in a case where the consideration is nominal, why should a similar result be ruled out because the option is created by deed and no consideration is expressed. ${ }^{37}$ One may also add to Sharpe's observation that equity's practice on volunteers and contracts under seal appears to be curiously inconsistent with the large number of cases in which equity has protected third party beneficiaries to simple contracts by a finding that the promisee was a trustee for the third party beneficiary. ${ }^{38}$ Certainly to a commercial practitioner it is astonishing that an option under seal is

32 Mountford v Scott [1974] 1 All ER 248 (Ch).

33 The decision proceeded on the assumption that the legal nature of an option was a contract to hold open an offer for acceptance: ibid, at 254. See also Stromdale \& Ball Ltd v Burden [1952] Ch 223 (Ch).

34 Mountford $v$ Scott, above $\mathrm{n} 32$, at 254. It may be noted that there was a nominal consideration in Milroy $v$ Lord, above n 24.

35 Mountford v Scott [1975] Ch 258 (CA).

36 Mountford v Scott, above n 32, at 255.

37 Robert J Sharpe Injunctions and Specific Performance (Canada Law Book Co, Toronto, 1983) at [744].

38 Tomlinson v Gill (1756) Ambler 330, 27 ER 221 (Ch); Gregory and Parker v Williams (1817) 3 Mer 582, 36 ER 224 (Ch); Lloyd's v Harper (1880) LR 16 Ch 290; Les Affréteurs Réunis Societe Anonyme v Walford 
less worthy of protection than an option "bought" for $\$ 1$, because a promise made in a deed is to be treated by equity as a nudum pactum unless supported by consideration.

The foregoing discussion illustrates why the reforms made recently in the Property Law Act 2007 are so significant. Section 18 now provides as follows:

18 Specific performance of voluntary promises made by deed

(1) A court-

(a) may make an order for the specific performance of a voluntary promise made by deed; but

(b) must not refuse to do so because there was no valuable consideration for the promise.

(2) Subsection (1) applies to deeds coming into operation only on or after 1 January 2008.

The writer considers that this is as it should be and that equity will now be required to treat a promise made to a third party beneficiary in a formal contract as a true obligation. Whether, and the extent to which it will choose to withhold a decree on discretionary grounds and whether the imperfect gift cases will survive, will have to wait for another day. For present purposes however it appears to the writer that no serious qualification needs to be made, at least in respect of New Zealand, to the thesis that assumption of obligation underlies the formal contract.

\section{B Part II}

When one moves to a discussion of the simple contract, one comes across an inescapable truth: one cannot understand the nature of the obligation undertaken therein if one divorces it from its historical roots. Chapter 2 of Professor Coote's Contract as Assumption develops the theme that it is the reciprocal exchange of the assumptions of legal obligation occurring simultaneously at the point of formation which brings a bilateral contract into being. What each party is seen to have bargained for is the assumption of a reciprocal obligation. In this part of the essay it will be demonstrated that the thesis is supported by the early cases on consideration and that the common law viewed mutual promises as consideration because a mutual executory agreement "imports in itself reciprocal actions upon the case". ${ }^{39}$ The idea that a promise animo contrahendi can be exchanged for a similar promise, however, leaves open an important question: is every promise valid in itself given in exchange for another promise and given with the intention to create legal relations enforceable? ${ }^{40}$

(London) Ltd [1919] AC 801 (HL); and see the cases collected by Arthur L Corbin "Contracts for the Benefit of Third Persons" (1930) 46 LQR 12.

39 Slade's case (1602) 4 Co Rep 92 b at 94 b, 76 ER 1074 (Exch Ch) at 1077.

40 See James Barr Ames Two Theories of Consideration (1899) 13 Harv L Rev 29, who argued for this proposition. 
And is it everything which the parties agree upon as the requested exchange which the law should treat as valid consideration provided it is not too vague, uncertain, or otherwise incapable of enforcement?

WT Barbour, in his History of Contract in Early English Equity ${ }^{41}$ wrote that the early history of consideration is wrapped in obscurity: "We do not know how or when it made its first appearance, and there is much dispute as to its source. But we do know that the first use of the word at common law was in the action of Assumpsit and that ultimately it became settled that no promise was enforceable unless it were made upon a valid consideration." 42

In his magisterial review of the modern history of the doctrine of consideration, Holdsworth suggested that at the beginning of the sixteenth century the word 'consideration' had not yet acquired its technical meaning. ${ }^{43}$ But towards the end of the 1500 s it seems reasonably clear that the term 'consideration' is taking the shape that a modern reader would instantly recognise. Stone $v$

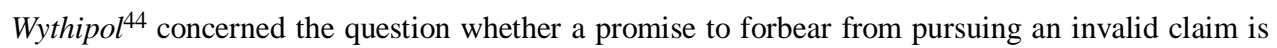
consideration. In that case the executor of an infant testator promised to pay the infant's debt if the creditor would forbear to sue. It was held that as the creditor could not have sued for this debt because an infant debtor's obligation was void, the creditor had not provided any consideration by forbearing to sue. Coke's argument which succeeded will be familiar to modern eyes: ${ }^{45}$

every consideration that doth charge the defendant in an assumpsit must be to the benefit of the defendant or charge of the plaintiff, and no case can be put out of this rule. And this contract by the infant was void; and staying of suit is no benefit to the defendant, nor any charge to the plaintiff more than was before.

It is clear that by the late 1500 s the term had begun to acquire its modern meaning. A number of early decisions are illustrative:

(1) Sir Anthony Sturlyn v Albany ${ }^{46}$ shows that the courts will respect the parties' autonomy and will not enquire into the adequacy of consideration (provided that it is sufficient in the eyes

41 WT Barbour The History of Contract in Early English Equity (Clarendon Press, Oxford, 1914) at 59-65.

42 On the respective ideas as to source see James Barr Ames "The History of Assumpsit" (1888) 2 Harv L Rev 1; John Salmond "History of Contract" (1886) 3 LQR 166 at 172; and Oliver Wendell Holmes "Early English equity" (1884) 1 LQR 162.

43 William Holdsworth "The Modern History of the Doctrine of Consideration" (1922) 2 B U L Rev 87. And see AWB Simpson "The Equitable Doctrine of Consideration and the Law of Uses" (1965) 16 UTLJ 1.

44 Stone v Wythipol (1588) Cro Eliz 126, 78 ER 383 (Ch).

45 Ibid, at 126-127.

46 Sturlyn v Albany (1587) Cro Eliz 67, 78 ER 327 (KB). 
of the law). ${ }^{47}$ In that case the plaintiff was a landlord who had granted a lease to the defendant's predecessor in title. The defendant promised that he would pay the rent if the plaintiff would show him the deed of lease under which the rents were made payable. The plaintiff duly dug out the contractual documents and showed them to the defendant. But the defendant failed to pay. The defendant argued that there was no consideration to support the promise for it is "but the shewing of the deed". But it was adjudged for the plaintiff: "for when a thing is to be done by the plaintiff, be it never so small, this is a sufficient consideration to ground an action". ${ }^{48}$

(2) In Filcocks $v$ Holt ${ }^{49}$ the plaintiff claimed that the defendant, a widow, promised to pay the plaintiff $£ 10$ in consideration that the plaintiff would permit her to take letters of administration in respect of her husband's estate as he had died intestate. Under the existing law a widow was entitled as of right to be administratrix. The plaintiff's promise was held to be no consideration as the promise was illusory and he had promised nothing "for by law she is to have administration being wife of the intestate."

47 Frederick Pollock Principles of Contract (13th ed, Stevens, London, 1950) at 139 cites Hobbes in support of the principle: "The value of all things contracted for is measured by the appetite of the contractors, and therefore the just value is that which they be contented to give." See Thomas Hobbes Leviathan (Cambridge University Press, Cambridge, 1996) at 105. And see Haigh v Brooks (1839) 10 A \& E 309, 113 ER 119 (QB).

48 For more modern illustrations of the same idea see Veitch v Sinclair [1975] 1 NZLR 264 (SC) at 270-271 where an otherwise worthless option document was an adequate consideration because the promisor purchased the document; Bainbridge v Firmstone (1838) 8 Ad \& E 743, 112 ER 1019 (QB) where there was a grant of permission to weigh one of two boilers which was consideration for a promise to give them up after weighing in as good a condition as before; Dunton v Dunton (1892) 18 VLR 114 (SC) where there was a promise by a wife to conduct herself with sobriety and in a respectable manner. For more old-fashioned illustrations see Bretton v Prettiman (1685) T Raym 153, 83 ER 82 (KB) where there was a promise to pay supported by the act of taking an oath before a master in chancery; March v Culpepper (1627) Cro Car 70, $79 \mathrm{ER} 662(\mathrm{~KB})$ where there was a promise to pay in return for examination of financial statements.

49 Filcocks and Holt's Case (1687) 1 Leon 240, 74 ER 219 (Exch Ch). For more modern illustrations of illusory promises providing no consideration, see British Empire Films Pty Ltd v Oxford Theatres Pty Ltd [1943] VLR 163 (SC) where it was held there was no consideration because an exemption clause provided that "under no circumstances shall the distributor be in any way liable for failure to supply to the exhibitor any of the films"; Loftus v Roberts (1902) 18 TLR 532 (CA) at 534:

wherever words which by themselves constituted a promise were accompanied by words which showed that the promisor was to have a discretion or option as to whether he would carry out that which purported to be the promise, the result was that there was no contract.

See also Taylor v Brewer (1813) 1 M \& S 290, 105 ER 108; MacRobertson Miller Airline Services v Commissioner of State Taxation (Western Australia) (1975) 133 CLR 125 at 132-133 where an exception clause "eats up" an obligation, making the promise illusory. And see Grover C Grismore Principles of the Law of Contracts (Revised ed, Bobbs-Merrill Co, Indianapolis, 1965) at 84: "if A says to B, I promise to pay you $\$ 100$ tomorrow if I do not change my mind in the meantime, this is not a sufficient consideration"; and Thorby $v$ Goldberg (1964) 112 CLR 597 at 605. 
(3) In Sherwood $v$ Woodward, ${ }^{50}$ Woodward had agreed to sell a certain quantity of cheese to Sherwood's son. Sherwood promised Woodward that if Woodward would perform his contract with his son and deliver the cheese, he Sherwood would pay for the cheese if his son did not. The cheese was delivered but neither the son nor Mr Sherwood paid. In an action by Woodward against Sherwood it was argued that no consideration had been received from Woodward to support Sherwood's promise to pay for the goods as Woodward was already bound to deliver the cheese under his pre-existing contract with Sherwood's son. But it is reported that Gawdy and Fenner JJ held it to be a good consideration "for it is an ease to the bargainee to have them without suit, which peradventure otherwise he could not have had." This is an interesting decision because it is an early illustration of the principle that even though the promisee suffers no detriment (he was already legally bound to deliver the cheese), the promisor might be liable if the requested act conferred a benefit on him. ${ }^{51}$

(4) In Strangborough $v$ Warner ${ }^{52}$ the report states "Note that a promise against a promise will maintain an action upon the case, as in consideration that you do give me $£ 10$ on such a day, I promise to give you $£ 10$ such a day after." This case, like several other similar contemporary cases, ${ }^{53}$ indicates that the Court recognised that reciprocal mutual promises were consideration for one another.

In all of these early cases the Court is attempting to identify those promises which are gratuitous or illusory from those in which there is an exchange for value. Consideration is the technique by which the law ensures the necessary reciprocity or mutuality which must exist for the enforcement of a promise. ${ }^{54}$ The courts will strive to give effect to the parties' own estimation of value so that

50 Sherwood v Woodward (1653) Cro Eliz 700, 78 ER 935 (QB).

51 For more modern illustrations see New Zealand Shipping Co v A M Satterthwaite [1974] 1 NZLR 505 (PC) at 51: "An agreement to do an act which the promisor is under an existing obligation to a third party to do may quite well amount to a valid consideration ... the promisee obtains the benefit of a direct obligation..."; Pao On v Lau Yin Long [1980] AC 614 (PC) at 632; Shadwell v Shadwell (1860) 9 C B (N S) 159, 142 ER 62 (CP); Scotson v Pegg (1861) 6 H \& N 295, 158 ER 121 (Exch). And see generally AG Davis "Promises to perform an existing duty" (1937) 6 CLJ 202.

52 Strangborough v Warner (1588) 4 Leon 3, 74 ER $686(\mathrm{~KB})$.

53 Wichals v Johns (1653) Cro Eliz 703, 78 ER 938: "A promise against a promise raises sufficient consideration to support an assumpsit"; Bettisworth v Campion (1608) Yelv 133, 80 ER 90 (KB): "The consideration on each part was the mutual promise of the one to the other." It is arguable that mutual promises have been consideration for one another since Pecke v Redman (1555) 2 Dy 113a, 73 ER 248 (KB): see Coke's treatment of that case in Slade's Case, above n 39, at 94 b.

54 In Hill v Haines [2007] EWCA 1284, [2008] Ch 412 (CA) at [79] Rix LJ said: "The doctrine is used in essence to distinguish the obligatory promise from the merely voluntary: the concept is based on the idea of reciprocity...". 
where some detriment to the promisee or some benefit to the promisor can be found, however slight, the court will respect the contracting parties' own estimation and not second guess their judgment on value. It will therefore not assess the adequacy of consideration. But where nothing of substance is promised in return, where neither benefit nor detriment can be found and the counter promise is gratuitous or illusory, the court will hold that the promise is unenforceable on the ground of want of consideration.

All of the above cases are cases on assumpsit, and they illustrate the truth of Barbour's observation that the first common usage of the term consideration at common law $^{55}$ was in assumpsit. What will not be apparent to modern eyes is that assumpsit was not in its early days a general remedy for breach of a simple contract. The role played by the forms of action prevented assumpsit being a general remedy for breach of contract. ${ }^{56}$ It was not until Slade's case ${ }^{57}$ that the way was opened to a general law of contract.

The facts in Slade's case were that Slade had sowed a crop of wheat and rye on his land in Devon. Morley agreed to take the whole crop and promised to pay $£ 16$ on a certain day. When Morley failed to pay, Slade brought action in assumpsit. It was found that a sale had been concluded and that there was no other promise or assumpsit other than the bargain previously referred to. After several judicial conferences it was held that the claim was maintainable. A plaintiff had the right to elect whether he brought his claim in debt or in assumpsit. In all cases where the Register had two writs for one and the same case it was in the plaintiff's election to take either. More significantly for our subject the Court resolved: ${ }^{58}$

that every contract executory imports in itself an assumpsit, for when one agrees to pay money, or to deliver any thing, thereby he assumes or promises to pay, or deliver it, and therefore when one sells any goods to another, and agrees to deliver them at a day to come, and the other in consideration thereof agrees to pay so much money as such a day, in that case both parties may have an ... action on the case on assumpsit for the mutual executory agreement of both parties imports in itself reciprocal actions upon the case...

55 See Simpson, above n 43, showing that before there was any doctrine of consideration in assumpsit there was a well developed equitable doctrine of consideration in relation to the law of uses.

56 See Maylard v Kester (1601) Moore 711, 72 ER 857 (QB). Maylard brought an action in assumpsit based on a sale of cloth. Maylard obtained judgment at trial for the value of the goods sold. The defendant sought error as the garments had been delivered. It was held that debt (and not assumpsit) was the proper claim "the matter proving a perfect sale and contract", so the judgment was overturned.

57 Slade's Case, above n 39.

58 Ibid, at 1077. 
Those final words should be noted. They show that the reason behind cases such as Strangborough $v$ Warner $^{59}$ is that when mutual promises are exchanged each party assumes a reciprocal obligation to the other (imports in itself reciprocal actions on the case).

In the Court's view what was occurring when Slade agreed to sell his crop to Morley and Morley agreed to pay $£ 16$ was that each party exchanged a legal obligation to perform the promise he had undertaken. It was as if the transaction were as follows: "if you Slade will assume an obligation to sell your crop and give me a simple contract right against you, I Morley will assume an obligation to pay you $£ 16$ and give you a simple contract right against me."

An essential ingredient in the creation of the contractual obligation in simple contract is therefore just as in the case of the formal contract, the promisor's assumption of a contractual obligation. ${ }^{60}$ As Professor Coote rightly detected: "It is the reciprocal exchange of the assumptions of legal contractual obligation, occurring simultaneously at the point of formation, which brings an executory bilateral contract into being. What each party is seen to have bargained for is the assumption, by the other, of reciprocal legal obligation to him or her." ${ }^{61}$ The law recognises when each promise is exchanged for the other that each may be a consideration for the other. A promise may constitute a consideration because when exchanged for the counter promise it confers a right of action in respect of the promise.

This is well illustrated by Nichols $v$ Raynbred, ${ }^{62}$ one of the earliest cases on discharge by breach of a simple contract. Nichols brought an assumpsit against Raynbred declaring that in consideration that Nichols promised to deliver to his own use a cow, the defendant promised to pay fifty shillings. The plaintiff had not pleaded delivery of the cow, and it was held that he need not do so because "it is promise for promise". Each party had a reciprocal right of action against the other. If the buyer wished to protect himself against having to pay the fifty shillings prior to the delivery of the cow he needed to condition his promise to pay against the prior or concurrent delivery of the cow, by the seller. 63

If, as Slade's case suggests, ${ }^{64}$ reciprocal promises may be consideration for each other because each assumes an obligation to the other party, and acquires an obligation in exchange, the question that arises is whether it is every promise given intending to assume a legal obligation which can be a

59 Strangborough $v$ Warner, above n 52

60 See Australian Woolen Mills Pty Ltd v The Commonwealth, above n 8, at 457.

61 Coote, above n 1 , at 39

62 Nichols v Raynbred (1614) Hob 88, 80 ER 238 (KB).

63 See generally SJ Stoljar "Dependent and Independent Promises" (1955) 2 Syd LR 217 on the early development of discharge by breach.

64 Slade's Case, above n 39, at 94b. 
consideration for a counter-promise similarly given. Is A's promise to transfer property enforceable if exchanged for a promise by B to accept the property, each being exchanged with an intention to create legal relations ? $^{65}$

In one sense one only needs to ask the question to know what the answer must be. When the Court of King's Bench allowed assumpsit to become the general remedy for breach of contract it imported into the law all the pre-existing precedents on assumpsit. We have seen that the law gives great respect to the contractual autonomy of the parties and will respect their assessment of the value of the requested exchange and will not investigate the adequacy of consideration. But the law does not enforce gratuitous and illusory promises and considers that an illusory promise given by A in exchange for a promise by $\mathrm{B}$ involves as a consequence that there is insufficient consideration to support B's promise. ${ }^{66}$

The idea that not every promise given in exchange for another promise was enforceable was already deeply ingrained into the law when assumpsit became the general remedy for breach of contract. It is an illusory promise for a promisor to promise to allow a widow to take letters of administration when the law gives her that right anyway. ${ }^{67}$ It is an illusory promise for a person to promise to forbear from bringing legal proceedings against an infant when the claim is known to be bad because such agreements are void. ${ }^{68}$ When a promisor makes such a promise he is promising nothing. The law requires that the counter-promise received by the defendant in exchange for his promise itself be of value. It will be of value if the act which was promised by the plaintiff is a detriment to the plaintiff or a benefit to the defendant. ${ }^{69}$

65 See Governors of Dalhousie College v Boutilier [1934] 3 DLR 593 (SC) at 596-597 where it was held there was no contract:

It was suggested that the statement in the subscription of the purpose for which it was made, viz of enabling Dalhousie College to maintain and improve the efficiency of its teaching ... constituted an implied request ... to apply the promised subscription to this object and that the acceptance by the college of his promise created a contract between them, the consideration for the promise ... to pay the money being the promise of the college to apply it for the purpose stated

See also Re Hudson (1885) 54 LJ Ch 811 (Ch); Re Cory (1912) 29 TLR 18 (Ch). But in Brokaw v McElroy 143 NW 1087 (Iowa 1913) it was suggested that the obligation of recipient trustees to apply a gift in accordance with their trust deed might support a promise to subscribe to the trust fund.

66 See cases cited at n 49; Arthur L Corbin Corbin on Contracts (West Publishing Company, St Paul, 1952) at [145].

67 Filcocks v Holt, above n 49.

68 Stone $v$ Wythipol, above n 44.

69 Bolton v Madden (1873) LR QB 55 (QB) at 56; Currie v Misa (1875) LR 10 Exch 153 (Exch Ch) at 162. Where there are promises to perform acts in the future (as there will be in a bilateral contract) it is logical to test whether a given promise is supported by consideration by examining whether when performed the relevant counterpromise will confer a benefit on the promisor or result in a detriment to the counterparty. If 
This is the stuff of consideration and the battle rages around any number of practical day to day issues: is forbearance to prosecute a claim which is known to be groundless and bad in law valuable consideration $?^{70}$ Is the payment of part of an existing debt, already due and owing, in instalments good consideration for a promise to release the balance $?^{71}$ Is the promise to perform an existing contractual duty made to the counterparty good consideration to support a promise to pay more money than was originally bargained for? ${ }^{72}$ Is the promise to perform a duty which one is already bound to perform to another party under a contract or a statute supported by consideration ${ }^{73}$ Is the promise not to bore my parent a valuable benefit? ${ }^{74}$ Or to look after my child well $?^{75}$ Is it valuable consideration to promise to pay $\$ 20$ in return for a promise to pay $\$ 100$, each amount to be paid in Auckland on the same day? ${ }^{76}$

The law examines the content of the counter-promise and requires that the performance of the obligation to be undertaken by the plaintiff counterparty will confer a benefit to the defendant or be a detriment to the plaintiff. As Blackburn J laid down: ${ }^{77}$

The general rule is, that an executory agreement, by which the plaintiff agrees to do something on the terms that the defendant agrees to do something else may be enforced if what the plaintiff has agreed to do is either for the benefit of the defendant or to the trouble or prejudice of the plaintiff ... If it be either, the adequacy of the consideration is for the parties to consider at the time of making the agreement, not for the Court when it is sought to be enforced.

it is concluded that the relevant counterpromise will confer a benefit on the promisor and is not an illusory or gratuitous promise, the promisor's promise and the counterpromise may be a consideration for one another. This follows because the mutual executory agreement of both parties imports in itself reciprocal actions on the case. The promisor is liable because by his promise he has assumed a legal obligation and has received in exchange an enforceable promise entitling him to the benefit of the counter-performance or its monetary equivalent.

70 Wade v Simeon (1846) 2 C B 548, 135 ER 1061 (CP).

71 Foakes v Beer (1884) 9 App Cas 605 (HL).

72 Stilkv Myrick (1809) 2 Camp 317, 170 ER 1168 (Assizes).

73 Scotson v Pegg (1861), above n 51.

74 White v Bluett (1853) 23 LJ Ex (NS) 36 (Exch).

75 Ward v Byham [1956] 2 All ER 318 (CA).

76 See Corbin, above n 66, at [129]. See also TP Shepherd \& Co v James A Rhodes 7 RI 470 (RI 1863) per Bullock J:

... at common law a contract for the exchange of unequal sums of money at the same time, or at different times, when the element of time is no equivalent is not binding; and in such cases the Courts may and do enquire into the equality of the contract; for its subject-matter upon both sides has not only a fixed value, but is itself the standard of all values...

77 Bolton v Madden (1873) LR 9 QB 55 (QB) at 56. 
It follows, therefore, that although a voluntary assumption of a legal duty is of the essence of a contract, it is still necessary to test whether any given promise will give rise to an enforceable obligation. Whether a purported assumption of liability contained in a counter promise is enforceable is answered in our law by asking whether what the plaintiff has agreed to do is either for the benefit of the defendant or to the trouble or prejudice of the plaintiff. The answers to these questions will assist in determining whether or not the promise is enforceable.

\section{Part III}

Against this background we may now return to Williams $v$ Roffey Bros ${ }^{78}$ The background to the case was that Roffey Bros \& Nicholls (Contractors) Ltd (hereafter "Roffey") were head contractors under a contract to refurbish an apartment block. The head contract contained penalty provisions for late completion. The plaintiff was a sub-contractor who had been retained by Roffey for a lump sum to do the carpentry work on the apartments in the block. After a substantial portion of the work had been done it became clear to Roffey that the plaintiff who had underbid on that contract was in financial difficulties, and might fail to complete the agreed work on time and might never finish it at all. ${ }^{79}$ Roffey thereupon approached the plaintiff and offered to increase the contract price by $£ 10,300$ if the plaintiff would go on with the contract and complete his performance. The additional money was to be paid at the rate of $£ 575$ for each apartment finished. By completing one flat at a time rather than working on all of them at the same time Roffey was able to direct its other trades to work in the completed flats. ${ }^{80}$ This allowed the work to be performed more efficiently. The plaintiff did substantially complete the work but Roffey failed to pay the additional amounts. It was accepted that no additional obligation had been undertaken by the plaintiff but it was clear that as a result of the revised arrangements the defendant had secured its commercial position and had derived an advantage. ${ }^{81}$

When the plaintiff sought to recover the additional amounts Roffey argued that the plaintiff had not agreed to undertake any new obligation, and therefore had not provided any consideration. ${ }^{82} \mathrm{By}$ contrast, the plaintiff argued that his promise to continue with the carpentry work and complete it on time would confer a benefit on Roffey and that to confer a benefit on the promisor was sufficient consideration. ${ }^{83}$ So the case raised in acute form whether it was sufficient for the plaintiff to show that his promise to complete would confer a benefit on the promisor even though he had not suffered

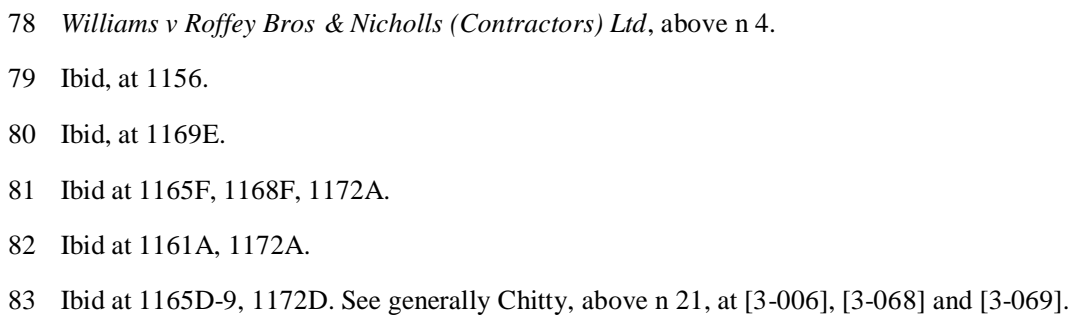


a detriment. Was the promise to perform or the performance by the plaintiff of his existing contractual duty to Roffey a sufficient consideration?

The English Court of Appeal held that the plaintiff could recover. It was thought that the defendants had obtained a practical benefit in ensuring a continuity of the subcontractor's work and in avoiding the trouble and expense of employing others to complete the work. The essence of the Court's approach can be found in Glidewell LJ's reasoning: ${ }^{84}$

... the present state of the law on this subject can be expressed in the following proposition: (i) if A has entered into a contract with B to do work for, or to supply goods or services to, B in return for payment by $\mathrm{B}$ and (ii) at some stage before A has completely performed his obligations under the contract B has reason to doubt whether A will, or will be able to, complete his side of the bargain; and (iii) B thereupon promises A an additional payment in return for A's promise to perform his contractual obligations on time; and (iv) as a result of giving his promise, B obtains in practice a benefit, or obviates a disbenefit; and (v) B's promise is not given as a result of economic duress or fraud on the part of A; then (vi) the benefit to $\mathrm{B}$ is capable of being consideration for B's promise, so that the promise will be legally binding.

In Contract as Assumption Professor Coote argues that Williams v Roffey Bros was wrongly decided. ${ }^{85} \mathrm{He}$ argues that Williams cannot have provided consideration by promising to perform his contract obligations because nothing new or additional was promised. Professor Coote was, however, alive to the possibility that the requested act of completing performance might confer a benefit in fact and support a unilateral contract but discounted this argument by reason of the House of Lords decision in Foakes $v$ Beer. ${ }^{86}$

Is it the case then that Foakes $v$ Beer decides that it can never be consideration for the plaintiff to promise to perform or to perform an act which is already contractually due to the defendant? ${ }^{87}$ And is that reasoning sound?

It will be remembered that in Foakes $v$ Beer, Lord Selborne found it impossible without refinements which would alter the sense of the word consideration to treat the payment of a part of a

84 Ibid, at 1165D-F.

85 Coote, above n 1, at 58-59.

86 Foakes $v$ Beer, above n 71. Mrs Beer had obtained a judgment for $£ 2,090.19$ s against Dr Foakes. Mrs Beer undertook not to take any proceedings on the judgment if Foakes paid $£ 500$ down and $£ 150$ semi-annually in instalments until the whole sum was paid off. Dr Foakes paid off $£ 2,090.19$ s whereupon Mrs Beer sought interest. The Court held she was entitled to do so as the agreement was nudum pactum being without consideration.

87 See Stilk v Myrick, above n 72; J O'Sullivan "In Defence of Foakes v Beer" [1996] CLJ 219. 
debt already due as being "supported by any new consideration proceeding from the debtor." He said: ${ }^{88}$

what is called any benefit ... is not (as I conceive) that sort of benefit which a creditor may derive from getting payment of part of the money due to him from a debtor who might otherwise keep him at arm's length, or possibly become insolvent ....

Likewise, Lord Fitzgerald thought that part payment of a debt cannot alone be the foundation of a parol satisfaction and discharge of the residue "as it brings no advantage to the creditor, and there is no consideration moving from the debtor who has done no more than partially to perform his obligation." 89 Lord Watson in turn thought that Mrs Beer should prevail on the simple ground that her agreement to abate part of her claim was nudum pactum for which the appellant gave no consideration. ${ }^{90}$ Clearly it can be inferred from these dicta that their Lordships subscribed to a view of consideration which saw the performance of an existing contractual duty as never being capable of constituting a sufficient benefit in the eyes of the law. It would no doubt be reasoned that the promise of the performance of an act which is already owed to the co-contracting party, is an illusory promise and therefore no consideration as it promises nothing which is not already due to the promisor.

Lord Blackburn, in his opinion in Foakes v Beer, attacked this conclusion. Giving the term 'benefit' its ordinary everyday meaning, he said that all men of business recognise that prompt payment of part of a debt may in certain circumstances be more beneficial to the creditor than to insist on his right to enforce payment of the whole debt. ${ }^{91}$ The proposition that it can never be a benefit to a creditor to accept less than he or she is due was, in Lord Blackburn's opinion, contrary to ordinary commercial experience. Lord Blackburn therefore differs from his brethren in thinking that a court is not precluded from finding a benefit to exist on the ground that the person making the promise was already obliged to provide the performance promised. Such a promise is not an illusory promise.

Interestingly, although their Lordships may have differed in their conclusions as to whether or not a part payment of a debt already due could amount in law to a benefit, there was a common element which underpinned all their reasoning. All of their Lordships believed that Lord Coke had said that it could never be a consideration for a creditor to accept a part payment of a debt to support

88 Foakes v Beer, above n 71, at 613-614.

89 Ibid, at 629.

90 Ibid, at 623

91 Ibid, at 618 and 622 . 
a promise not to enforce the debt. Their Lordships all considered that this had been resolved in Pinnel's Case. ${ }^{92}$

Although it is true that Lord Coke had said that for the purposes of the defence of an accord and satisfaction to a claim in debt, part payment could not be satisfaction, he had actually also said that a part payment could be consideration to support an assumpsit not to enforce the debt. In Bagge v Slade $e^{93}$ it was thought by Coke $\mathrm{J}$ that the promise to release a debt of $£ 1,000$ was supported by a consideration of payment of $£ 500$. In that case Coke J distinguished between the satisfaction of a debt and an agreement for consideration not to enforce the debt and said: "also if a man be bound to another by a bill in $£ 1,000$ and he pays unto him $£ 500$ in discharge of this bill, the which he accepts of accordingly, and doth upon this assume and promise to deliver up unto him his said bill of $£ 1,000$, this $£ 500$ is no satisfaction of the $£ 1,000$ but yet this is good and sufficient to make a good promise and upon a good consideration". 94

Likewise, in Goring $v$ Goring ${ }^{95}$ it was held that a promise by a debtor to pay part of his debt to his creditor was consideration for a promise by the creditor to release him from payment of the whole. This was held to be a valid agreement on sufficient consideration. In that case the Court said that although the plaintiff had not shown that he had discharged the defendant of the $£ 205$, "yet if the defendant should be afterwards charged with it, he might have an assumpsit against the plaintiff; for the plaintiff agreeing to take $£ 150$ for $£ 205$ is a promise on his part, and so one promise against another". In Rawlins v Lockey ${ }^{96}$ judgment was recovered upon such a promise, the Court saying: "For though legally after the obligation is forfeited, 30 pounds can be no satisfaction for 60 pounds, yet to have the money in his hands without suit is a good consideration to maintain this action upon the promise."

It can be argued in such cases that the creditor is the best judge of his own interests and that the Courts should respect the parties' autonomy. Although the promise to pay part of a debt which is already due has the hallmarks of an illusory promise (in that all that is being promised is already legally due to the promisor), in fact such a promise may not always be illusory. If the creditor bargains for such a promise and it can be shown that the creditor will obtain a benefit in fact from the performance of that promise, it was thought by Lord Coke and his fellow Judges that there was sufficient consideration to support a promise not to enforce the debt. The reasoning was that

92 Ibid, at 612, 617-618, 624 and 628.

93 Bagge v Slade (1614) 3 Bulst 162, 81 ER 137 (KB).

94 Ibid, at 162.

95 Goring v Goring (1602) Yelv 11, 80 ER 8 (KB).

96 Rawlins v Lockey (1639) 1 Vin Abr 308; See also Reynolds v Pinhowe (1595) Cro Eliz 429, 78 ER 669 $(\mathrm{KB})$ : "it is a benefit to him to have it without suit or charge"; Johnson v Astell (1667) 1 Lev 198, 83 ER 367 $(\mathrm{KB})$ : "Payment without suit or trouble of that which is due is a good consideration". 
although part payment of a debt was not satisfaction of the debt for the purposes of an accord and satisfaction of a debt, ${ }^{97}$ it could nevertheless be sufficient consideration to support a promise that the creditor not bring an action on the debt.

None of these cases are mentioned in the judgments and no one who has read Bagge $v$ Slade can plausibly accuse Lord Coke, as Lord Blackburn did in Foakes v Beer, of having thought that part payment of a debt could never be a benefit to the creditor constituting a consideration to support a promise.

A judge can hardly be blamed for not referring to relevant authority when counsel has failed to advance the critical argument and cite the relevant decisions. But it does not follow that when those cases are ultimately brought to the court's attention and the errors of the earlier reasoning revealed that those errors should be repeated. The truth is that the reasoning of all their Lordships in Foakes $v$ Beer is flawed in that they failed to note the important distinction that Lord Coke had drawn between satisfaction of claims in debt and actions in contract.

Of course it might have been the case that even had all the cases been cited to their Lordships, they would have stuck to their guns and held that a promise to perform a part of what is already due is an illusory promise which cannot constitute consideration. That is a possibility. ${ }^{98}$

However, in the writer's opinion if the relevant cases had been cited to the Court in support of an argument distinguishing between a part payment as satisfaction of a pre-existing debt, and as consideration to support a promise not to enforce the balance, the result would, in all probability, have been different. For then precedent would have been the ally of Lord Blackburn's common sense approach and not its opponent. And the Court could have arrived at a result which at least some of their Lordships appeared to consider was a more sensible outcome. ${ }^{99}$

97 In Pinnel's Case (1602) 5 Co Rep 117a, 77 ER 237 (CP) it was said that for the purposes of an action in debt:

It was resolved by the whole court that payment of a lesser sum on the day in satisfaction of a greater cannot be any satisfaction for the whole because it appears to the Judges that by no possibility a lesser sum can be a satisfaction to the plaintiff for a greater sum.

98 Two of the relevant decisions were actually before their Lordships. Counsel for the appellant cited Reynolds $v$ Pinhowe, above $\mathrm{n} 96$, and counsel for the respondent cited Goring $v$ Goring, above $\mathrm{n} 95$. But counsel for the appellant did not distinguish between part payment of an existing debt as a satisfaction and as consideration to support an assumpsit. Goring $v$ Goring appears to have been cited in support of the proposition in Pinnel's Case, ibid, without adverting to the distinction between debt and contract.

99 See also James Barr Ames "Two Theories of Consideration" (1899) 12 Harv L Rev 515 at 527:

It is greatly to be deplored that the case of Bagge $v$ Slade, and the other similar cases, were not brought to the attention of the Court. Had Coke's real opinion, as expressed in that case, been made to the Lords, it is not improbable that they would have followed it, instead of making him stand sponsor for a doctrine contrary to his declared convictions. 
In the writer's opinion, Williams $v$ Roffey Bros is not a new departure and no novelty. It is in fact a return to the reasoning that underlies the early cases such as Goring v Goring and Bagge $v$ Slade. It has adopted a view that benefit to the promisor may be a sufficient consideration even where no detriment moves from the promisee. That approach is as old as the doctrine of consideration itself and in the writer's view supported by a considerable body of case law. The difference between Williams v Roffey Bros and other cases on existing legal duty such as Stilk v Myrick is that the Court has been prepared to go beyond finding that the promise to perform an existing duty must be an illusory promise, to consider whether on the facts there was the promise of an act requested by the defendant promisor which if performed by the plaintiff promisee would confer a benefit on the promisor. This is, as Glidewell LJ suggested in Williams v Roffey Bros, a refinement of Stilk v Myrick. Where, as in Williams v Roffey Bros, it can be demonstrated that the defendant promisor bought a promise from the plaintiff from which he would receive a benefit, it is no departure from established principle to find the existence of a consideration. 